\title{
Pharmacogenetics and Forensic Toxicology: A New Step towards a Multidisciplinary Approach
}

\author{
Nunzio Di Nunno ${ }^{1, \dagger}$, Massimiliano Esposito ${ }^{2,+}\left(\mathbb{D}\right.$, Antonina Argo ${ }^{3} \mathbb{D}$, Monica Salerno ${ }^{2, *, \ddagger}$ \\ and Francesco Sessa $4, *, \ddagger$ (D)
}

1 Department of History, Society and Studies on Humanity, University of Salento, 73100 Lecce, Italy; nunzio.dinunno@unisalento.it

2 Department of Medical, Surgical and Advanced Technologies "G.F. Ingrassia”, University of Catania, 95121 Catania, Italy; massimiliano.esposito91@gmail.com

3 Department of Health Promotion Sciences, Section of Legal Medicine, Maternal and Infant Care, Internal Medicine and Medical Specialties (PROMISE), University of Palermo, Via del Vespro, 129, 90127 Palermo, Italy; antonella.argo@unipa.it

4 Department of Clinical and Experimental Medicine, University of Foggia, 71122 Foggia, Italy

* Correspondence: monica.salerno@unict.it (M.S.); francesco.sessa@unifg.it (F.S.); Tel.: +39-095-3782-153 or +39-333-2466-148 (M.S.); +39-088-1736-926 (F.S.)

+ These authors contributed equally to this work.

$\ddagger$ These authors share last authorship.

Citation: Di Nunno, N.; Esposito, M.; Argo, A.; Salerno, M.; Sessa, F. Pharmacogenetics and Forensic Toxicology: A New Step towards a Multidisciplinary Approach. Toxics 2021, 9, 292. https://doi.org/10.3390/ toxics 9110292

Academic Editors: Guido Cavaletti and Michael Petriello

Received: 27 September 2021

Accepted: 2 November 2021

Published: 4 November 2021

Publisher's Note: MDPI stays neutral with regard to jurisdictional claims in published maps and institutional affiliations.

Copyright: (c) 2021 by the authors. Licensee MDPI, Basel, Switzerland. This article is an open access article distributed under the terms and conditions of the Creative Commons Attribution (CC BY) license (https:// creativecommons.org/licenses/by/ $4.0 /)$.

\begin{abstract}
Pharmacogenetics analyzes the individual behavior of DNA genes after the administration of a drug. Pharmacogenetic research has been implemented in recent years thanks to the improvement in genome sequencing techniques and molecular genetics. In addition to medical purposes, pharmacogenetics can constitute an important tool for clarifying the interpretation of toxicological data in post-mortem examinations, sometimes crucial for determining the cause and modality of death. The purpose of this systematic literature review is not only to raise awareness among the forensic community concerning pharmacogenetics, but also to provide a workflow for forensic toxicologists to follow in cases of unknown causes of death related to drug use/abuse. The scientific community is called on to work hard in order to supply evidence in forensic practice, demonstrating that this investigation could become an essential tool both in civil and forensic contexts. The following keywords were used for the search engine: (pharmacogenetics) AND (forensic toxicology); (pharmacogenetics) AND (post-mortem); (pharmacogenetics) AND (forensic science); and (pharmacogenetics) AND (autopsy). A total of 125 articles were collected. Of these, 29 articles were included in this systematic review. A total of $75 \%$ of the included studies were original articles $(n=21)$ and $25 \%$ were case reports $(n=7)$. A total of $78 \%(n=22)$ of the studies involved deceased people for whom a complete autopsy was performed, while $22 \%(n=6)$ involved people in good health who were given a drug with a subsequent pharmacogenetic study. The most studied drugs were opioids (codeine, morphine, and methadone), followed by antidepressants (tricyclic antidepressants and venlafaxine). Furthermore, all studies highlighted the importance of a pharmacogenetics study in drug-related deaths, especially in cases of non-overdose of drugs of abuse. This study highlights the importance of forensic pharmacogenetics, a field of toxicology still not fully understood, which is of great help in cases of sudden death, deaths from overdose, deaths after the administration of a drug, and also in cases of complaint of medical malpractice.
\end{abstract}

Keywords: pharmacogenetics; forensic toxicology; multidisciplinary approach; molecular autopsy; drug-related death

\section{Introduction}

Forensic science is a multidisciplinary science that uses the principles of different fields, such as chemistry, physics, and biology, in order to supply the so-called "weight of evidence" [1-6]. 
In this multidisciplinary context, the forensic toxicology laboratory aims to identify and quantify the presence of drugs and other chemical substances in biological fluids collected during autopsy [7-9]. Moreover, the toxicological investigation could be performed for medico-legal purposes (i.e., drug and alcohol tests for commercial driver licensing or involving occupational medicine due to the consequences of workers exposed to toxic substances) $[10,11]$.

In forensic toxicology, it is essential to understand the pivotal role of pharmacogenetics (the study of how genetic variations give rise to differences in drug response), considering that pharmacokinetics and pharmacodynamics, and therefore the bioavailability of a drug, are conditioned by a genetic substrate. In forensic pathology, the diagnosis of the cause of death is guaranteed by the results of the crime scene investigation, anamnesis, autopsy, and toxicological data [12-15]. In this scenario, pharmacogenetics may be helpful to solve toxicological puzzles, especially in cases of suicides, accidents, and death by unknown causes. The possible influence of pharmacogenetics on drug metabolism should also be considered when interpreting the post-mortem concentration of a substance in body fluids or organs.

The term 'pharmacogenetics' is commonly used to describe the study of inter-individual variations in the DNA sequence that may affect the pharmacokinetics or pharmacodynamics of the drug. Indeed, these variations may influence genes encoding transporter proteins and enzymes that metabolize drugs, receptors, etc. [16]. The goal of pharmacogenetics is to predict the individual response to the drug and evaluate its effects. In clinical practice, pharmacogenetics is used to assess the ability of a patient, or a group of patients, to develop the desired effect or, conversely, to develop adverse effects $[17,18]$. Pharmacogenetic research has been implemented in recent years thanks to the improvement of genome sequencing techniques and molecular genetics. In medicine, pharmacogenetic research has two crucial functions: to identify disease-specific genes and gene products, and to identify allelic variants that influence the response to therapy [19].

Furthermore, pharmacogenetics may represent an important tool to clarify the interpretation of toxicological data in post-mortem examinations, sometimes crucial for determining the cause and modality of death. In fact, forensic pathologists are often implicated in deaths related to the use/abuse of drugs and narcotics [20]. For example, the CYP2D6 (Cytochrome P450 Family 2 Subfamily D Member 6) gene is involved in the metabolism of some drugs, such as morphine and its derivatives (codeine, tramadol, dihydrocodeine, oxycodone), and some CYP2D6 polymorphisms can reduce methadone clearance. Instead, CYP3A4 is involved in the metabolism of benzodiazepines and buprenorphine [21]. Thus, determining the presence of cytochrome inducing or suppressing mutations can provide answers in cases of death related to a suspected drug overdose [22].

Table 1 shows the main genetic polymorphisms of cytochromes involved in pharmacogenetics.

Table 1. Main enzymes involved in drug metabolism in forensic toxicology.

\begin{tabular}{cr}
\hline \multicolumn{2}{c}{ Drugs of Toxicological Interest and Their Metabolizing Enzymes [22-24] } \\
\hline Gene Involved in Drug Metabolization & Drugs Metabolized \\
\hline CYP2C19 & $\begin{array}{c}\text { Amitriptylineim, Ipramine, Diazepam, Citalopram, Carisoprodol, } \\
\text { several Anticonvulsants }\end{array}$ \\
\hline CYP2D6 & $\begin{array}{c}\text { Amphetamines, Codeine, Oxycodone, Hydrocodone, Methadone, Tramadol, some } \\
\text { Antipsychotics, some Tricyclic Antidepressants, Steroids }\end{array}$ \\
\hline CYP3A4 & $\begin{array}{c}\text { Benzodiazepines, Fentanyl, Methadone, Buprenorphine, Hypnotics, some } \\
\text { Antipsychotics, some Tricyclic Antidepressants }\end{array}$ \\
\hline CYP2E1 & Ethanol, some Anaesthetics, Paracetamol, Verapamil
\end{tabular}

The purpose of this systematic literature review is not only to raise awareness among the forensic community regarding pharmacogenetics, but also to provide a workflow for forensic toxicologists to follow in cases of unknown causes of death related to drug 
use/abuse. The scientific community is called on to work hard in order to supply evidence in forensic practice, demonstrating that this investigation could become an essential tool both in civil and forensic contexts.

\section{Materials and Methods}

A systematic review was conducted.

SCOPUS was used as the search engine from 1 January 1980 to 1 August 2021 to evaluate the association between pharmacogenetics and forensic toxicology. The following keywords were used: (pharmacogenetics) AND (forensic toxicology); (pharmacogenetics) AND (post-mortem); (pharmacogenetics) AND (forensic sciences); and (pharmacogenetics) AND (autopsy).

\subsection{Inclusion and Exclusion Criteria}

The following exclusion criteria were used: (1) review, (2) articles not in English, (3) abstract, (4) poster, and (5) communications at conferences. The inclusion criteria were as follows: (1) Original Article, (2) Case Report, (3) Articles in English, (4) In Vivo Studies, and (5) In Vitro Studies.

\subsection{Quality Assessment and Data Extraction}

M.E. and F.S. initially evaluated all the articles, evaluating the title, the abstract, and the whole text. M.S., then, reanalyzed the articles chosen independently. In cases in which there were conflicting opinions regarding the articles, they were submitted to C.P.

\subsection{Characteristics of Eligible Studies}

A total of 125 articles were collected. Of these, 24 duplicates were removed. A total of 72 articles did not meet the inclusion criteria. In conclusion, 29 articles were included in the present systematic review (Figure 1).

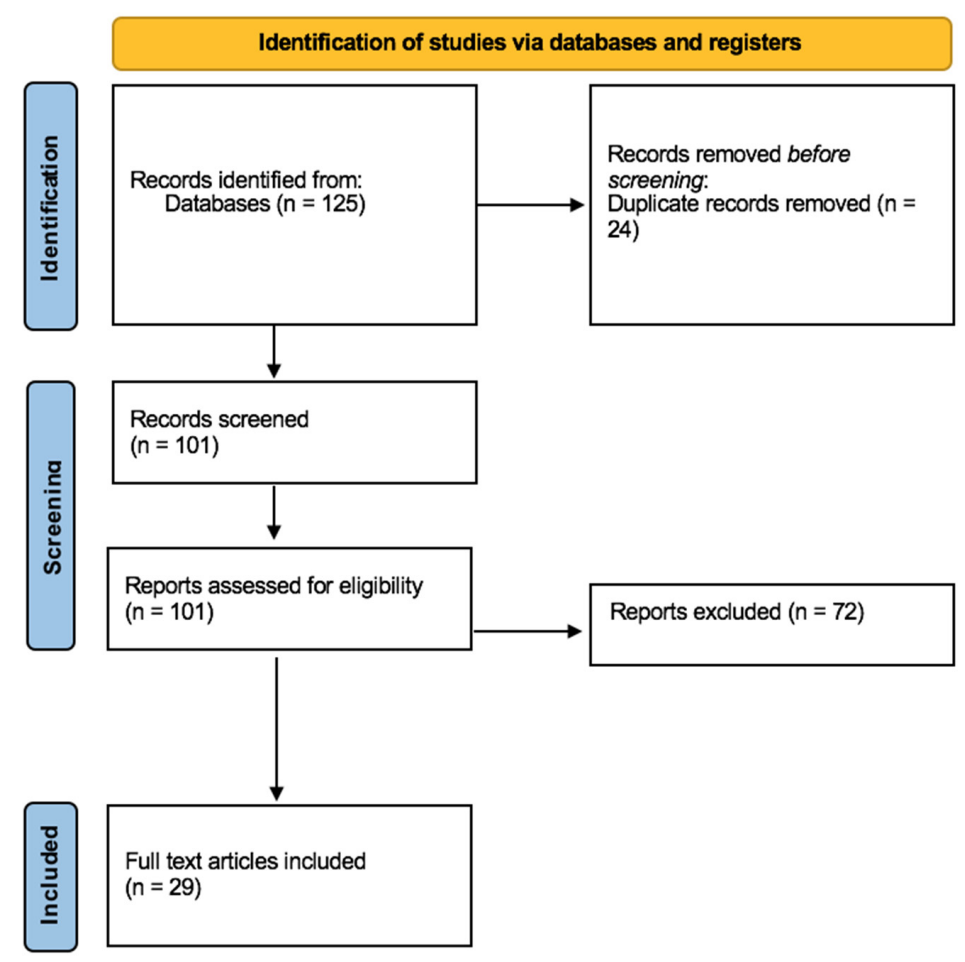

Figure 1. Flow diagram illustrating included and excluded studies in this systematic review.

\section{Results}

All selected studies are summarized in Table 2. 
Table 2. Summary of the details of the systematic review.

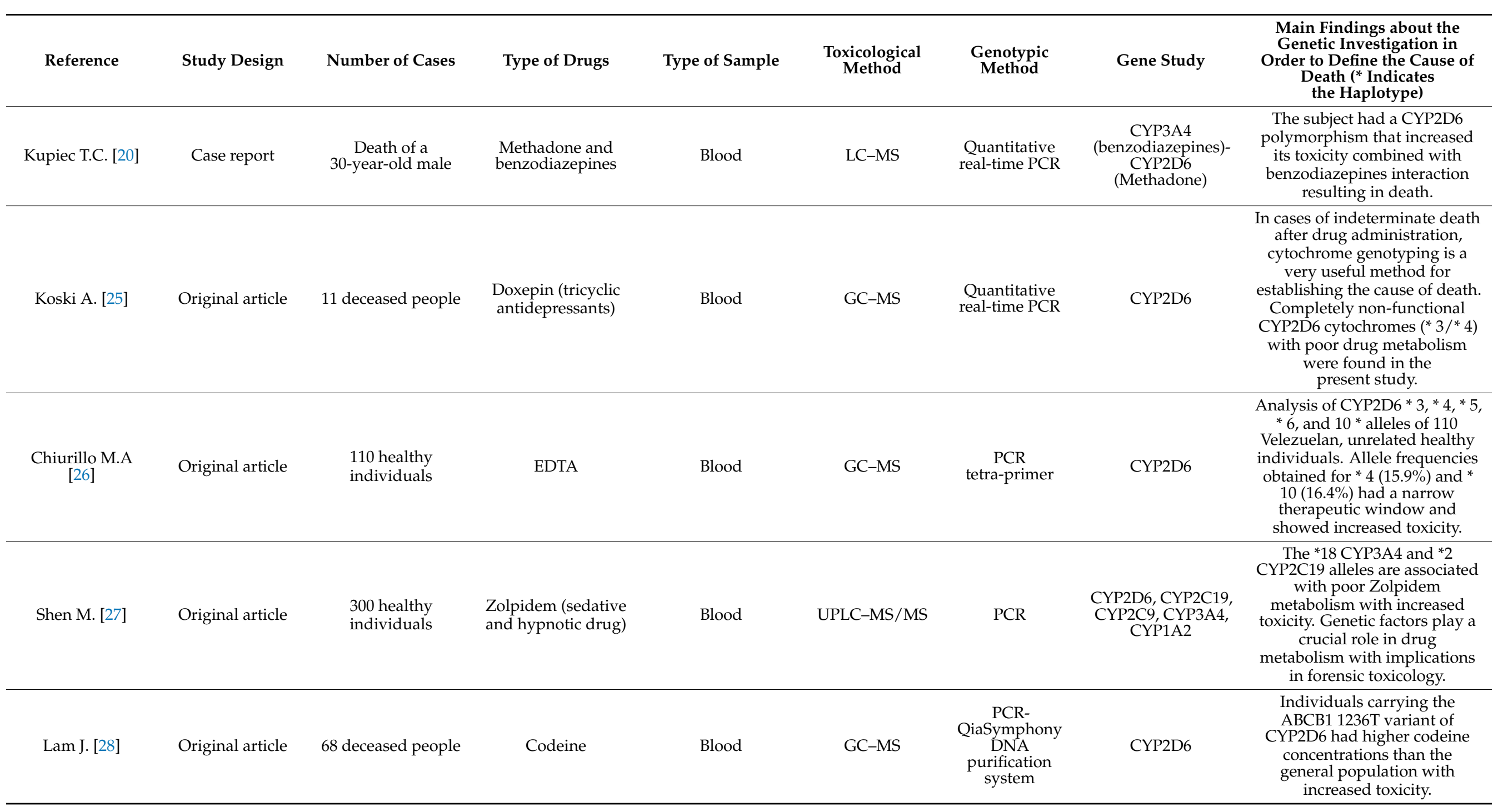


Table 2. Cont.

\begin{tabular}{|c|c|c|c|c|c|c|c|c|}
\hline Reference & Study Design & Number of Cases & Type of Drugs & Type of Sample & $\begin{array}{l}\text { Toxicological } \\
\text { Method }\end{array}$ & $\begin{array}{l}\text { Genotypic } \\
\text { Method }\end{array}$ & Gene Study & $\begin{array}{l}\text { Main Findings about the } \\
\text { Genetic Investigation in } \\
\text { Order to Define the Cause of } \\
\text { Death (* Indicates } \\
\text { the Haplotype) }\end{array}$ \\
\hline Høiseth G. [30] & Original article & $\begin{array}{l}75 \text { Healthy } \\
\text { individuals }\end{array}$ & $\begin{array}{c}\text { Carisoprodol } \\
\text { (muscle relaxant) }\end{array}$ & Blood & GC-MS & $\begin{array}{l}\text { TaqMan-based } \\
\text { realtime } \\
\text { PCR assays }\end{array}$ & CYP2C19 & $\begin{array}{l}\text { This study found no evidence } \\
\text { of an association between } \\
\text { CYP2C19 genetics and the } \\
\text { mortality risk of carisoprodol. }\end{array}$ \\
\hline Thieme D. [31] & Original article & $\begin{array}{l}23 \text { Healthy } \\
\text { individuals }\end{array}$ & $\begin{array}{l}\text { Amitriptyline, } \\
\text { Nortriptyline } \\
\text { (Tricyclic } \\
\text { Antidepressant) }\end{array}$ & Hair & LC-MS & $\begin{array}{l}\text { TaqMan-based } \\
\text { realtime } \\
\text { PCR assays }\end{array}$ & CYP2D6, CYP2C19 & $\begin{array}{l}\text { The genotypes of CYP2C19 } \\
\text { (alleles * }{ }^{*}, * 3 \text {, and } * 4 \text { ) and } \\
\text { CYP2D6 }(* 3, * 4 \text {, and } * 6 \text { ) were } \\
\text { examined and a substantial } \\
\text { change in metabolites was seen } \\
\text { from the wild-type variant. }\end{array}$ \\
\hline Koski A. [32] & Original article & $\begin{array}{l}202 \text { deceased } \\
\text { people }\end{array}$ & $\begin{array}{l}\text { Amitriptyline } \\
\text { (Tricyclic } \\
\text { Antidepressant) }\end{array}$ & Blood & LC-MS & $\begin{array}{l}\text { Long PCR } \\
\text { reactions }\end{array}$ & CYP2D6, CYP2C19 & $\begin{array}{l}\text { Pharmacogenetic analysis of } \\
\text { CYP2D6 and CYP2C19 } \\
\text { genotypes is of great help in } \\
\text { cases of subjects who die after } \\
\text { drug administration. }\end{array}$ \\
\hline $\begin{array}{l}\text { Tawfik Khattab } \\
\text { A.M. [33] }\end{array}$ & Original article & $\begin{array}{l}187 \text { Healthy } \\
\text { individuals }\end{array}$ & $\begin{array}{c}\text { Organophosphorus } \\
\text { drugs }\end{array}$ & Blood & GC-MS & $\begin{array}{l}\text { Long PCR } \\
\text { reactions }\end{array}$ & CYP2D6, CYP2C19 & $\begin{array}{l}\text { In some populations, some } \\
\text { genetic polyforms are very } \\
\text { frequent, so it is important to } \\
\text { consider this in } \\
\text { pharmacogenetics. }\end{array}$ \\
\hline$\underset{[34]}{\text { Neukamm M.A. }}$ & Case report & 52-year-old female & $\begin{array}{l}\text { Doxepin (Tricyclic } \\
\text { Antidepressants) }\end{array}$ & Blood & LC-MS & PCR & CYP2D6 & $\begin{array}{l}\text { The death of the woman was } \\
\text { due to a cytochrome } \\
\text { polymorphism and an } \\
\text { interaction with other drugs } \\
\text { rather than an overdose. }\end{array}$ \\
\hline
\end{tabular}


Table 2. Cont.

\begin{tabular}{|c|c|c|c|c|c|c|c|c|}
\hline Reference & Study Design & Number of Cases & Type of Drugs & Type of Sample & $\begin{array}{l}\text { Toxicological } \\
\text { Method }\end{array}$ & $\begin{array}{l}\text { Genotypic } \\
\text { Method }\end{array}$ & Gene Study & $\begin{array}{c}\text { Main Findings about the } \\
\text { Genetic Investigation in } \\
\text { Order to Define the Cause of } \\
\text { Death (* Indicates } \\
\text { the Haplotype) }\end{array}$ \\
\hline $\begin{array}{c}\text { Launiainen } \mathrm{T} . \\
{[36]}\end{array}$ & Original article & $\begin{array}{l}123 \text { deceased } \\
\text { people }\end{array}$ & $\begin{array}{c}\text { Venlafaxine } \\
\text { (serotonin and } \\
\text { norepinephrine } \\
\text { reuptake } \\
\text { inhibitors- } \\
\text { SSNRIs) } \\
\end{array}$ & Blood & GC-MS & $\begin{array}{l}\text { Long PCR } \\
\text { reactions }\end{array}$ & CYP2D6 & $\begin{array}{l}\text { This study found no evidence } \\
\text { of an association between } \\
\text { CYP2D6 genetics and the } \\
\text { mortality risk of venlafaxine. }\end{array}$ \\
\hline Jakobsson G. [38] & Original article & $\begin{array}{l}174 \text { deceased } \\
\text { people }\end{array}$ & $\begin{array}{l}\text { Oxycodone } \\
\text { (opioid) }\end{array}$ & Blood & LC-MS & $\begin{array}{c}\text { Digital } \\
\text { droplet PCR }\end{array}$ & CYP2D6 & $\begin{array}{l}\text { In toxicology, not only the } \\
\text { concentration of metabolites in } \\
\text { the blood is important to } \\
\text { assess drug toxicity, but also } \\
\text { the genotyping of cytochromes. } \\
\text { A fast or slow phenotype } \\
\text { changes the toxicity of a drug. } \\
\text { A pharmacogenetic study } \\
\text { should always be performed. }\end{array}$ \\
\hline
\end{tabular}


Table 2. Cont.

\begin{tabular}{|c|c|c|c|c|c|c|c|c|}
\hline Reference & Study Design & Number of Cases & Type of Drugs & Type of Sample & $\begin{array}{c}\text { Toxicological } \\
\text { Method }\end{array}$ & $\begin{array}{l}\text { Genotypic } \\
\text { Method }\end{array}$ & Gene Study & $\begin{array}{c}\text { Main Findings about the } \\
\text { Genetic Investigation in } \\
\text { Order to Define the Cause of } \\
\text { Death (* Indicates } \\
\text { the Haplotype) }\end{array}$ \\
\hline Wu A.H. [40] & Case report & Young woman & Codeine & Blood & LC-MS & $\begin{array}{l}\text { Quantitative } \\
\text { real-time PCR }\end{array}$ & $\begin{array}{c}\text { CYP2D6, UGT2B7, } \\
\text { CYP3A4 }\end{array}$ & $\begin{array}{l}\text { In this case report, a young } \\
\text { woman had taken codeine and } \\
\text { caused a car accident. The } \\
\text { young woman initially went to } \\
\text { jail. However, through a } \\
\text { pharmacogenetic study, it was } \\
\text { possible to state that she was } \\
\text { not in a state of acute } \\
\text { intoxication so this element } \\
\text { provided evidence for } \\
\text { her release. }\end{array}$ \\
\hline Bastami S. [41] & Original article & $\begin{array}{l}20 \text { Healthy } \\
\text { individuals }\end{array}$ & Tramadol (opioid) & Blood & HPLC & $\begin{array}{c}\text { Quantitative } \\
\text { real-time PCR }\end{array}$ & CYP2D6 & $\begin{array}{l}\text { The study of the CYP2D6 } \\
\text { genotype helps to establish } \\
\text { with greater certainty the } \\
\text { metabolic relationship of } \\
\text { tramadol with its metabolite to } \\
\text { evaluate the time of } \\
\text { drug intake. }\end{array}$ \\
\hline Levo A. [42] & Original article & $\begin{array}{l}33 \text { deceased people } \\
\text { (11 males and } \\
22 \text { females) }\end{array}$ & Tramadol (opioid) & Blood & LC-MS & PCR & CYP2D6 & $\begin{array}{l}\text { The genetic variation of drug } \\
\text { metabolizing enzymes is } \\
\text { substantial and can be studied } \\
\text { in forensic toxicology. } \\
\text { Furthermore, genetic factors } \\
\text { play a dominant role in the } \\
\text { metabolism of } \\
\text { individual drugs. }\end{array}$ \\
\hline Koren G. [43] & Case report & Male infant & $\begin{array}{l}\text { Codeine and } \\
\text { Paracetamol }\end{array}$ & Blood & GC-MS & PCR & CYP2D6 & $\begin{array}{l}\text { The CYP2D6*2A allele with } \\
\text { CYP2D6 } * 2 \times 2 \text { gene } \\
\text { duplication (ultra-rapid } \\
\text { metaboliser) resulted in } \\
\text { increased morphine formation } \\
\text { from codeine, resulting in } \\
\text { drowsiness and the death of } \\
\text { the child. }\end{array}$ \\
\hline
\end{tabular}


Table 2. Cont.

\begin{tabular}{|c|c|c|c|c|c|c|c|c|}
\hline Reference & Study Design & Number of Cases & Type of Drugs & Type of Sample & $\begin{array}{l}\text { Toxicological } \\
\text { Method }\end{array}$ & $\begin{array}{l}\text { Genotypic } \\
\text { Method }\end{array}$ & Gene Study & $\begin{array}{c}\text { Main Findings about the } \\
\text { Genetic Investigation in } \\
\text { Order to Define the Cause of } \\
\text { Death (* Indicates } \\
\text { the Haplotype) }\end{array}$ \\
\hline $\begin{array}{l}\text { Rahikainen A.L. } \\
{[45]}\end{array}$ & Original article & 349 suicide cases & $\begin{array}{l}\text { Citalopram } \\
\text { (antidepressant of } \\
\text { the selective } \\
\text { serotonin reuptake } \\
\text { inhibitor class) }\end{array}$ & Blood, & LC-MS & PCR & P-gp & $\begin{array}{l}\text { Genetic variation in efflux } \\
\text { transporter and permeability } \\
\text { glycoprotein (P-gp) in women } \\
\text { taking citalopram was } \\
\text { associated with completed } \\
\text { violent suicides and even } \\
\text { violent suicide attempts. }\end{array}$ \\
\hline Drevin G. [46] & Case report & 35-year-old man & $\begin{array}{l}\text { Ethanol, Morphine, } \\
\text { Antidepressants }\end{array}$ & Blood & GC-MS & $\begin{array}{l}\text { Taqman } \\
\text { real-time } \\
\text { PCR analyses }\end{array}$ & CYP2D6, CYP2C19 & $\begin{array}{l}\text { Cytochrome genotyping is a } \\
\text { very useful method for } \\
\text { establishing the cause of death. }\end{array}$ \\
\hline Fonseca S. [48] & Original article & $\begin{array}{l}100 \text { deceased } \\
\text { people }\end{array}$ & Tramadol (opioid) & Blood & GC-MS & $\begin{array}{l}\text { Quantitative } \\
\text { real-time PCR }\end{array}$ & CYP2D6 & $\begin{array}{l}\text { Poor metabolizers have very } \\
\text { low metabolic capacity and } \\
\text { higher metabolic ratios. The } \\
\text { metabolism of tramadol is } \\
\text { correlated with the phenotype } \\
\text { of the metabolizer and it is } \\
\text { essential to know the } \\
\text { phenotype in cases of } \\
\text { opioid-related deaths. }\end{array}$ \\
\hline Buchard A. [49] & Original article & 90 deceased people & $\begin{array}{l}\text { Methadone } \\
\text { (opioid) }\end{array}$ & Blood & GC-MS & $\begin{array}{l}\text { Quantitative } \\
\text { real-time PCR }\end{array}$ & P-gp MDR1gene & $\begin{array}{l}\text { This study found no evidence } \\
\text { of an association between } \\
\text { P-glycoprotein MDR1 gene } \\
\text { genetics and the mortality risk } \\
\text { of methadone. }\end{array}$ \\
\hline
\end{tabular}


Table 2. Cont.

\begin{tabular}{|c|c|c|c|c|c|c|c|c|}
\hline Reference & Study Design & Number of Cases & Type of Drugs & Type of Sample & $\begin{array}{c}\text { Toxicological } \\
\text { Method }\end{array}$ & $\begin{array}{l}\text { Genotypic } \\
\text { Method }\end{array}$ & Gene Study & $\begin{array}{c}\text { Main Findings about the } \\
\text { Genetic Investigation in } \\
\text { Order to Define the Cause of } \\
\text { Death (* Indicates } \\
\text { the Haplotype) }\end{array}$ \\
\hline Karlsson L. [50] & Original article & 94 deceased people & $\begin{array}{c}\text { Venlafaxine } \\
\text { (selective serotonin } \\
\text { and } \\
\text { norepinephrine } \\
\text { reuptake } \\
\text { inhibitors-SSNRIs) }\end{array}$ & Blood & GC-MS & $\begin{array}{l}\text { Quantitative } \\
\text { real-time PCR }\end{array}$ & CYP2C19, CYP2D6 & $\begin{array}{c}\text { The CYP2D6 genotype } \\
\text { influences the } \\
\text { O-demethylation of } \\
\text { venlafaxine, while CYP2C19 } \\
\text { influences the } \\
\text { N-demethylation of } \\
\text { venlafaxine, which affects the } \\
\text { toxicity of this drug. }\end{array}$ \\
\hline Andresen H. [51] & Original article & 11 deceased people & $\begin{array}{l}\text { Morphine and } \\
\text { codeine }\end{array}$ & Blood & GC-MS & $\begin{array}{c}\text { Quantitative } \\
\text { real-time PCR }\end{array}$ & CYP2D6 & $\begin{array}{l}\text { Pharmacogenetic evaluation in } \\
\text { forensic toxicology is essential, } \\
\text { as the genetic polymorphisms } \\
\text { of cytochromes play a key role } \\
\text { in drug toxicity. }\end{array}$ \\
\hline Jannetto P.J. [52] & Original article & 25 deceased people & Fentanyl & Blood & GC-MS & $\begin{array}{l}\text { Quantitative } \\
\text { real-time PCR }\end{array}$ & CYP3A4, CYP3A5 & $\begin{array}{l}\text { Post-mortem data are evidence } \\
\text { that CYP3A4 and CYP3A5 are } \\
\text { involved in the metabolism of } \\
\text { fentanyl. In particular, } \\
\text { homozygous CYP3AS*3 } \\
\text { causes an altered metabolism } \\
\text { of fentanyl with an increase in } \\
\text { its concentration in the blood. } \\
\text { Pharmacogenetics and } \\
\text { molecular autopsy are crucial } \\
\text { in these deaths. }\end{array}$ \\
\hline
\end{tabular}


More that $75 \%$ of the included studies $(n=29)$ were original articles $(n=22)$, while about $25 \%$ were case reports $(n=7)$. In 22 of the included studies, a complete autopsy was performed, while about $20 \%(n=6)$ concerned healthy people who had died after drug administration with a subsequent pharmacogenetic study. Opioids (codeine, morphine, and methadone) were used in most of the analyzed cases, followed by antidepressants (tricyclic antidepressants and venlafaxine). Only in one study ethylenediaminetetraacetic (EDTA) anticoagulant [26] and organophosphorus drugs [33] were administered [26,33,37]. A blood analysis was performed in all cases with one exception: in this case, a hair sample was used to analyze genetic polymorphism [31]. In one report, different post-mortem samples were analyzed, such as saliva, spleen, and buccal swabs [37]. The analysis of the techniques used to perform the toxicological investigation showed that gas chromatography-mass spectrometry (GC-MS) was the gold standard method, followed by liquid chromatographymass spectrometry (LC-MS). Moreover, gas chromatography (GC) and high-performance liquid chromatography (HPLC) were used in two studies [35,41]. Only in one study was the toxicological investigation performed by a tandem mass spectrometer (UPLC-MS/MS) [27].

The most common method to analyze genetic polymorphisms was Polymerase Chain Reaction (PCR): the most investigated among the genetic polymorphisms was CYP2D6, followed by CYP2C19. Only two studies $[47,49]$ were concerned with P-glycoprotein, and only one study referred to cytochrome UGT2B7 [40].

Analyzing all selected studies, the importance of pharmacogenetics as a pivotal tool in order to define the exact cause of death was clear, while for three studies $[30,36,49]$ the cause of death remained unclear. Different genetic polymorphisms of the genes encoding cytochromes were investigated, determining changes in the bioavailability of the used drug and an increase in its toxicity. In several studies, it was reported that, although the drugs were administrated at the correct dosage, either due to the interaction with other drugs or due to the altered metabolization caused by these allelic variants, toxicity increased, causing the death of the subject [31-35,52-58]. In addition to the single nucleotide polymorphisms (SNPs) of the cytochrome genes, other genetic variations were investigated on the genes encoding for P-glycoprotein (P-gp). For example, Neuvonen A.M. et al. [47] analyzed the blood of 112 deceased people, clarifying a direct link between ABCB1 polymorphisms and the increase in mortality after digoxin treatment, suggesting a pivotal role for genotyping analysis.

Finally, all studies highlighted the importance of a pharmacogenetic study in drugrelated deaths, especially in cases in which an overdose on illicit drugs, alcohol, prescription medications, and other kinds of substances was not found [19,25-51]. In these cases, the evaluation of different polymorphisms that could be related to drug assumption is strongly recommended [33]. The main findings of the genetic investigation in order to define the cause of death are summarized in Table 2.

\section{Discussion}

Forensic pharmacogenetics is a field of toxicology that studies and analyzes the genotypes and allelic variants of genes encoding enzymes involved in drug metabolism [53-57]. The results of the present review confirmed that one of the most studied genes is CYP2D6, which encodes a member of the cytochrome P450 superfamily of enzymes. Beause of the genetic polymorphisms of the CYP2D6 gene, there are four main phenotypes: ultra-rapid metabolisers (UM); extensive metabolisers (EM); poor metabolisers (PM), lacking functional enzymes due to defective or deleted the relative genes; and intermediate metabolisers (IM), carrying alleles that partially decrease enzyme activity [58]. A recent review [59] affirmed that $7 \%$ of people who died from an opioid overdose had an ultra-rapid phenotype with increased the toxic effect. As summarized in Table 1, the forensic interest in genotyping this cytochrome is related to its involvement in the metabolism of opioids and other similar drugs. Indeed, it plays a pivotal role in the metabolism of endocannabinoid arachidonoylethanolamide (anandamide), 20-hydroxyeicosatetraenoic acid ethanolamide (20-HETE-EA), and 8,9-, 11,12-, and 14,15-epoxyeicosatrienoic acid ethanolamides (EpETrE- 
EAs), potentially modulating the endocannabinoid system signaling [60,61]. It is well described that the polymorphisms of this gene may influence the metabolism of fatty acids, steroids, and retinoids [62-65]. Moreover, its involvement in the oxidative metabolism of drugs, such as adrenoceptor antagonists, antiarrhythmics, and tricyclic antidepressants, has been demonstrated $[60,61,66]$.

The CYP2D6 gene, as all enzymes belonging to the CYP class, is responsible for the hepatic phase I metabolism of foreign substances and drugs [67]. The P450 family convert drugs into electrophilic intermediates, which are then conjugated by phase II enzymes (e.g., UDP glucuronosyltransferase and $\mathrm{N}$-acetyltransferase), and finally excreted. Although at least 60 P450 genes exist, the most studied subsets are CYP1A2, CYP2A6, CYP2B6, CYP2C19, CYP2D6, CYP2E1, and CYP3A4, which are responsible for the metabolism of the vast majority of prescription and over-the-counter drugs [68].

Considering this evidence, this enzyme is of medico-legal relevance. In addition, many antidepressants (e.g., nortriptyline) can also increase their toxicity and cause severe side effects in the presence of rapid or ultra-rapid metabolisers of CYP2D6. Therefore, understanding the CYP2D6 haplotype information of all metabolizer phenotypes can be very relevant to the forensic community $[69,70]$.

Indeed, Koren et al. [43] and Koski et al. [25] performed targeted CYP2D6 genotyping of some deaths to investigate the cause and/or modalities of death in a number of medicolegal cases. Furthermore, the case described by Koren et al. [43] of CYP2D6 genotyping was a classic example of the ultra-rapid metabolism of codeine to morphine, resulting in increased toxicity and in the subject's death.

The study of CYP enzyme cytochromes plays a fundamental role in these cases. Furthermore, these enzymes are not only expressed in the liver, but also in other cells, such as those of the central nervous system (CNS) [71-73].

These results correspond to those discussed in this systematic review: as summarized in Table 2, the CYP2C19 and CYP3A4 genes are frequently investigated in order to determine the possible influence of the genetic predisposition and the cause of death. Indeed, Shen M. et al. [28], in a study of 300 healthy individuals that were administered Zolpidem, affirmed that the *18 CYP3A4 and *2 CYP2C19 alleles were associated with poor metabolism, increasing the drug's toxicity. Genetic factors play a crucial role in drug metabolism with important implications in forensic toxicology. Ciszkowski C. [29], in a case study about the death of a healthy 2-year-old boy after codeine and acetaminophen administration, reported that cytochrome P-450 2D6 (CYP2D6) was genotyped and revealed a functional duplication of the CYP2D6 allele, resulting in an ultrafast metabolizer phenotype. A similar result was published by Koren G. et al. [43], concerning sudden death after codeine administration due to the genetic polymorphism of CYP2D6. The codeine prescribed was within the recommended range; however, the increased conversion of codeine to morphine resulted in the toxic buildup of morphine. In another study [34], a 52-year-old female died after the administration of doxepin (Tricyclic Antidepressants); the analysis of blood through LC-MS, allowed the authors to state that the death of the woman was due to a cytochrome polymorphism and an interaction with other drugs, rather than an overdose. Furthermore, Wu A.H. [40] reported that, in a case report of a young woman who took codeine and caused a car accident, the pharmacogenetic study allowed them to affirm that she was not in a state of acute intoxication, thus this element provided evidence for her release from jail. Deaths related to venlafaxine administration and due to rapid drug metabolism with increased toxicity and patient death have also been reported $[44,50]$.

$\mathrm{P}$-gp is another protein involved in the functionality of drugs that affect the CNS, especially psychotropic drugs. These drugs not only bind to the receptor, such as the dopamine D2 receptor (D2-R), but also to P-gp and other metabolic enzymes, and is encoded by the MDR1 (or ABCB1) gene. In particular, P-gp is a $170 \mathrm{kDa}$ ATP-dependent drug transporter and plays an important role in protecting the brain from potentially harmful substances [74,75]. Interindividual and population differences play a decisive role in the functionality of endogenous toxins, psychotropic drugs, and xenobiotics [76]. 
As explained in the present systematic review, Neuvonen A.M. [47] analyzed 112 deaths following the administration of digoxin, and the pharmacogenetic study using quantitative real-time PCR showed a link between ABCB1 polymorphisms and increased mortality, suggesting genotyping analysis prior to digoxin treatment. However, another study [49] did not report an increased risk of mortality after the MDR1gene pharmacogenetic study of Pgp after methadone administration. Further studies are needed to evaluate the importance of P-gp in forensic toxicology.

Another protein studied in pharmacogenetics is the p11 protein (also called S100A10), which plays a key role in the dynamic modulation of serotonin and has been implicated in major depressive disorder (MDD) and in the activity of antidepressant drugs. Some p11 genotypes have been shown to respond less to antidepressant therapy, causing increased suicides [77]. However, in the present systematic review, there are no studies evaluating the importance of this protein in forensic toxicology; future toxicological studies can clarify this aspect in cases of suicides.

According to Budowle et al. [78], the analysis of genetic variation and its effects on metabolism should be applied in sudden, unexplained suicides or deaths associated with chronic or acute drug therapy, even in sudden cardiac deaths [79]. Agrawal et al. [80], in a recent review, show that pharmacogenetics, through the study of gene polymorphisms, is a very useful tool in toxicology. Gene variants of enzymes that metabolize or transport drugs change the bioavailability and the therapeutic/toxic dose of the drug. In forensic toxicology, whole blood sampling is preferred for the pharmacogenetic study. Furthermore, chronic drug intake should also be considered in these cases, as there is an impact provided by acquired tolerance to drugs. Therefore, a person's death can result from even very low concentrations of a drug, since they have not developed tolerance to it [81].

Sajantila et al. [82] argue that pharmacogenetics has great implications in malpractice claims cases. A doctor, in fact, could administer a drug during the hospitalization of a patient in a dosage considered normal; however, that drug may either not have the intended therapeutic effect or be harmful and cause death. It is not possible to use pharmacogenetics alone, but only in addition to the data of the crime scene investigation, pathology, and forensic histopathology. The correlation and the multidisciplinary approach guarantee with certainty the cause of death and the evaluation of the behavior of healthcare professionals in cases of malpractice claims [83].

A recent study [84] declared that, in the future, molecular autopsy and pharmacogenetics will be increasingly important and will play a key role in determining drug-related and sudden deaths.

The present study highlights the importance of forensic pharmacogenetics, a field of toxicology still not fully understood, which is of great help in cases of sudden death, overdose-related deaths, deaths after the administration of a drug, and also in cases of malpractice claims. In fact, to date, this genetic investigation is not routinely used in these types of death and leads the forensic pathologist to make mistakes in the establishing of the cause of death [85-87]. Therefore, the purpose of this study is to provide the forensic community with a workflow to follow in cases of deaths related to the administration of drugs or substances of abuse (Figure 2). For the study of forensic pharmacogenetics, it is desirable that the forensic unit have a genetics laboratory, allowing for a complete genetic investigation [88]. Obviously, the costs of the analysis depend on the updating of techniques; those of the latest generations have a higher cost [89]. For example, Stamer et al. [90] in 2002 showed in their study that genotyping by real-time PCR with hybridization probes produced more reliable results than conventional PCR, but at much higher costs. Furthermore, according to Muller et al. [91], the real-time long-PCR analysis provides cytochrome genotyping results in 1 working day with a practical time of $3-4 \mathrm{~h}$. A 2012 review [92] concluded that real-time PCR should be used routinely in these kinds of analyses, considering the easy availability of this molecular analysis and also the low cost. An original article from 2010 confirmed that PCR gave reliable and low-cost results in forensic applications [93]. To date, more recent studies have shown that forensic genetics 
should always be used routinely in forensic practice [94,95]. Molecular techniques, such as PCR, are consolidated and widespread in the forensic field. Particularly molecular autopsy is an indispensable tool for the pathologist in order to define the cause of death. Usage times are also much shorter with reliable results in approximately one day. These aspects should encourage the forensic pathologist to always introduce these molecular techniques, such as PCR, now well-known not only in the microbiology field [96-100].

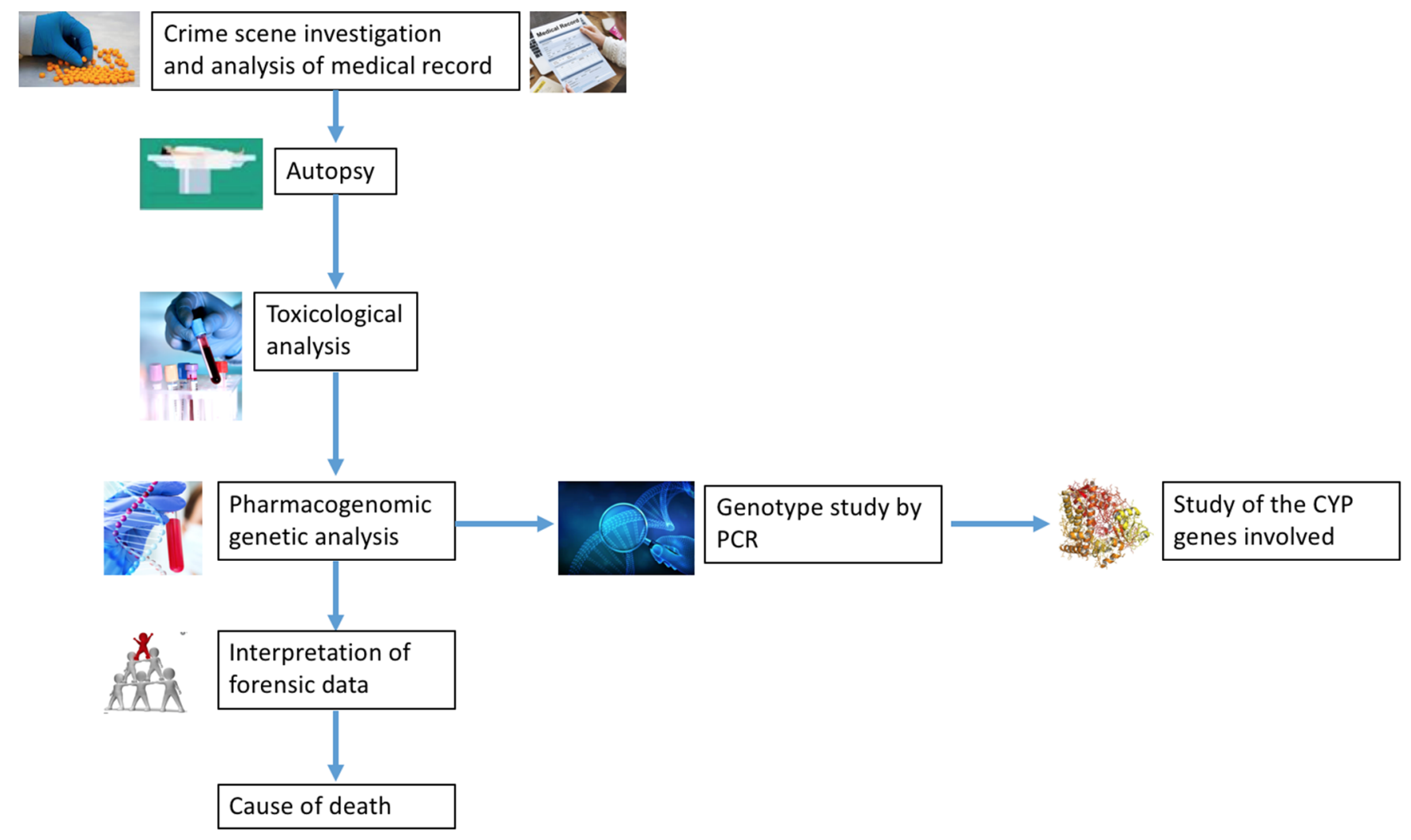

Figure 2. Investigative protocol for cases of suspected death related to the administration of drugs or abuse of substances. It is necessary to perform a DNA investigation, through a PCR test, analyzing the CYPs involved for the substance suspected of having been administered.

\section{Conclusions}

To date, drug-related deaths are very common and new drugs are emerging [101-104]. However, there is an increase in deaths also related to the use of other commonly used drugs used for chronic diseases (antidepressants, antipsychotics, and non-steroidal antiinflammatory NSAIDs). These deaths not only occur at home, but also in hospital, and are often related to complaints of malpractice by relatives [105-109]. In this scenario, these new techniques, posed at the center between toxicology and genetics, allow the forensic team to reach a certain diagnosis of the cause of death and not to make mistakes [110-112]. In the same manner, further studies should be conducted in order to identify new molecular biomarkers that could be useful both for forensic purposes, such as the identification of the cause of death, and for the identification of abuse drugs [113-115].

Based on the results of this systematic review, in the forensic field, gene investigation should be performed in relation to the hypothesis of the drug assumption: the most investigated genes are CYP2C19, CYP2D6, and CYP3A4.

The application of pharmacogenetics has important repercussions from both medicallegal and ethical points of view. The management of informed consent and the DNA database collection represent important concerns that should be considered before the introduction of the genetic unit in a forensic institute. Moreover, one of the most important problems is the informativeness of genetic testing, which could raise issues related to 
uncertain paternity. In this way, relatives may not consent to pharmacogenetic tests being carried out, and this may have repercussions on establishing the truth. Considering the application of pharmacogenetics to forensic science, it will be necessary to take into account these considerations both in practical applications and in the research field.

In the same manner, the multidisciplinary approach is a well-established approach in the forensic field that has to enter into the routine practice of the forensic field. This is highlighted by this systematic review by providing the forensic team with a workflow to use in cases of suspected drug-related death.

Author Contributions: Conceptualization, F.S. and M.S.; methodology, M.E., N.D.N. and A.A.; software, F.S.; validation, M.S.; formal analysis, M.E., N.D.N., A.A., M.S. and F.S.; investigation, M.E.; resources, M.S. and F.S.; data curation, M.E., N.D.N. and A.A.; writing-original draft preparation, M.E.; writing—review and editing, F.S.; visualization, M.E.; supervision, M.S.; project administration, F.S.; funding acquisition, M.S. All authors have read and agreed to the published version of the manuscript.

Funding: This research received no external funding.

Institutional Review Board Statement: Not applicable.

Informed Consent Statement: Not applicable.

Data Availability Statement: Data sharing is not applicable; no new data were created or analyzed in this study.

Acknowledgments: The authors thank the Scientific Bureau of the University of Catania.

Conflicts of Interest: The authors declare no conflict of interest.

\section{References}

1. Ferrara, M.; Sessa, F.; Rendine, M.; Spagnolo, L.; De Simone, S.; Riezzo, I.; Maglietta, F. A multidisciplinary approach is mandatory to solve complex crimes: A case report. Egypt. J. Forensic Sci. 2019, 9, 1-7. [CrossRef]

2. Ledda, C.; Pomara, C.; Bracci, M.; Mangano, D.; Ricceri, V.; Musumeci, A.; Rapisarda, V. Natural carcinogenic fiber and pleural plaques assessment in a general population: A cross-sectional study. Environ. Res. 2016, 150, 23-29. [CrossRef] [PubMed]

3. Spagnolo, L.; Bertozzi, G.; Ferrara, M.; Fiore, C.; Sessa, F. From crime scene investigation to the identification of the cause of death: A muscle-popping case report. Rom. J. Leg Med. 2018, 26, 340-343.

4. Filetti, V.; Di Mizio, G.; Rendine, M.; Fortarezza, P.; Ricci, P.; Pomara, C.; Sessa, F. Volatile organic compounds: Instrumental and canine detections link an individual to the crime scene. Egypt. J. Forensic Sci. 2019, 9, 1-11. [CrossRef]

5. Montana, A.; Rapisarda, V.; Esposito, M.; Amico, F.; Cocimano, G.; Nunno, N.D.; Ledda, C.; Salerno, M. A Rare Case of Suicide by Ingestion of Phorate: A Case Report and a Review of the Literature. Healthcare 2021, 9, 131. [CrossRef] [PubMed]

6. Maiellaro, A.; Perna, A.; Giugliano, P.; Esposito, M.; Vacchiano, G. Sudden Death from Primary Cerebral Melanoma: Clinical Signs and Pathological Observations. Healthcare 2021, 9, 341. [CrossRef] [PubMed]

7. Pomara, C.; Fiore, C.; D’Errico, S.; Riezzo, I.; Fineschi, V. Calcium oxalate crystals in acute ethylene glycol poisoning: A confocal laser scanning microscope study in a fatal case. Clin. Toxicol. 2008, 46, 322-324. [CrossRef]

8. Orban, G.; Bombardi, C.; Marino Gammazza, A.; Colangeli, R.; Pierucci, M.; Pomara, C.; Pessia, M.; Bucchieri, F.; Benigno, A.; Smolders, I.; et al. Role(s) of the 5-HT2C receptor in the development of maximal dentate activation in the hippocampus of anesthetized rats. CNS Neurosci. Ther. 2014, 20, 651-661. [CrossRef]

9. Sessa, F.; Franco, S.; Picciocchi, E.; Geraci, D.; Chisari, M.G.; Marsala, G.; Salerno, M. Addictions substance free during lifespan. Acta Med. Mediterr. 2018, 34, 2081-2087. [CrossRef]

10. Rapisarda, V.; Loreto, C.; Castorina, S.; Romano, G.; Garozzo, S.F.; Musumeci, A.; Migliore, M.; Avola, R.; Cinà, D.; Pomara, C.; et al. Occupational exposure to fluoro-edenite and prevalence of anti-nuclear autoantibodies. Future Oncol. 2018, $14,59-62$. [CrossRef] [PubMed]

11. Ledda, C.; Iavicoli, I.; Bracci, M.; Avola, R.; Senia, P.; Santarelli, L.; Pomara, C.; Rapisarda, V. Serum lipid, lipoprotein and apolipoprotein profiles in workers exposed to low arsenic levels: Lipid profiles and occupational arsenic exposure. Toxicol Lett. 2018, 282, 49-56. [CrossRef] [PubMed]

12. Fineschi, V.; Neri, M.; Di Donato, S.; Pomara, C.; Riezzo, I.; Turillazzi, E. An immunohistochemical study in a fatality due to ovarian hyperstimulation syndrome. Int. J. Leg. Med. 2006, 120, 293-299. [CrossRef] [PubMed]

13. Esposito, M.; Montana, A.; Liberto, A.; Filetti, V.; Nunno, N.D.; Amico, F.; Salerno, M.; Loreto, C.; Sessa, F. Anaphylactic Death: A New Forensic Workflow for Diagnosis. Healthcare 2021, 9, 117. [CrossRef] [PubMed] 
14. Monda, V.; Salerno, M.; Sessa, F.; Bernardini, R.; Valenzano, A.; Marsala, G.; Zammit, C.; Avola, R.; Carotenuto, M.; Messina, G.; et al. Functional Changes of Orexinergic Reaction to Psychoactive Substances. Mol. Neurobiol. 2018, 55, 6362-6368. [CrossRef] [PubMed]

15. Sessa, F.; Salerno, M.; Pomara, C. Autopsy Tool in Unknown Diseases: The Experience with Coronaviruses (SARS-CoV, MERS-CoV, SARS-CoV-2). Medicina 2021, 57, 309. [CrossRef] [PubMed]

16. Spear, B.B.; Heath-Chiozzi, M.; Huff, J. Clinical application of pharmacogenetics. Trends Mol. Med. 2001, 7, 201-204. [CrossRef]

17. Pirmohamed, M. Pharmacogenetics: Past, present and future. Drug Discov. Today 2011, 16, 852-861. [CrossRef]

18. Roses, A.D. Pharmacogenetics and the practice of medicine. Nature 2000, 405, 857-865. [CrossRef] [PubMed]

19. Wolf, C.R.; Smith, G.; Smith, R.L. Pharmacogenetics. BMJ 2000, 320, 987-990. [CrossRef]

20. Kupiec, T.C.; Raj, V.; Vu, N. Pharmacogenomics for the forensic toxicologist. J. Anal. Toxicol. 2006, 30, 65-72. [CrossRef]

21. Lötsch, J.; Skarke, C.; Liefhold, J.; Geisslinger, G. Genetic predictors of the clinical response to opioid analgesics: Clinical utility and future perspectives. Clin. Pharmacokinet. 2004, 43, 983-1013. [CrossRef]

22. Tamminga, W.J.; Wemer, J.; Oosterhuis, B.; De Zeeuw, R.A.; De Leij, L.F.; Jonkman, J.H. The prevalence of CYP2D6 and CYP2C19 genotypes in a population of healthy Dutch volunteers. Eur. J. Clin. Pharmacol. 2001, 57, 717-722. [CrossRef] [PubMed]

23. Poolsup, N.; Li Wan Po, A.; Knight, T.L. Pharmacogenetics and psychopharmacotherapy. J. Clin. Pharm. Ther. 2000, 25, 197-220. [CrossRef] [PubMed]

24. Druid, H.; Holmgren, P. A compilation of fatal and control concentrations of drugs in postmortem femoral blood. J. Forensic Sci. 1997, 42, 79-87. [CrossRef]

25. Koski, A.; Ojanperä, I.; Sistonen, J.; Vuori, E.; Sajantila, A. A fatal doxepin poisoning associated with a defective CYP2D6 genotype. Am. J. Forensic Med. Pathol. 2007, 28, 259-261. [CrossRef]

26. Chiurillo, M.A.; Grimán, P.; Morán, Y.; Camargo, M.E.; Ramírez, J.L. Analysis of CYP2D6 gene variation in Venezuelan population: Implications for forensic toxicology. Forensic Sci. Int. Genet. Suppl. Ser. 2009, 2, 483-484. [CrossRef]

27. Shen, M.; Shi, Y.; Xiang, P. CYP3A4 and CYP2C19 genetic polymorphisms and zolpidem metabolism in the Chinese Han population: A pilot study. Forensic Sci. Int. 2013, 227, 77-81. [CrossRef] [PubMed]

28. Lam, J.; Woodall, K.L.; Solbeck, P.; Ross, C.J.; Carleton, B.C.; Hayden, M.R.; Koren, G.; Madadi, P. Codeine-related deaths: The role of pharmacogenetics and drug interactions. Forensic Sci. Int. 2014, 239, 50-56. [CrossRef] [PubMed]

29. Ciszkowski, C.; Madadi, P.; Phillips, M.S.; Lauwers, A.E.; Koren, G. Codeine, ultrarapid-metabolism genotype, and postoperative death. New Engl. J. Med. 2009, 361, 827-828. [CrossRef] [PubMed]

30. Høiseth, G.; Majid, U.; Mørland, J.; Bramness, J.G.; Molden, E. CYP2C19 genetics in fatal carisoprodol intoxications. Eur. J. Clin. Pharmacol. 2012, 68, 1561-1565. [CrossRef] [PubMed]

31. Thieme, D.; Rolf, B.; Sachs, H.; Schmid, D. Correlation of inter-individual variations of amitriptyline metabolism examined in hairs with CYP2C19 and CYP2D6 polymorphisms. Int. J. Legal. Med. 2008, 122, 149-155. [CrossRef] [PubMed]

32. Koski, A.; Sistonen, J.; Ojanperä, I.; Gergov, M.; Vuori, E.; Sajantila, A. CYP2D6 and CYP2C19 genotypes and amitriptyline metabolite ratios in a series of medicolegal autopsies. Forensic Sci. Int. 2006, 10, 177-183. [CrossRef] [PubMed]

33. Tawfik Khattab, A.M.; Zayed, A.A.; Ahmed, A.; AbdelAal, A.G.; Mekdad, A.A. The role of PON1 and CYP2D6 genes in susceptibility to organophosphorus chronic intoxication in Egyptian patients. Neurotoxicology 2016, 53, 102-107. [CrossRef]

34. Neukamm, M.A.; Vogt, S.; Hermanns-Clausen, M.; Naue, J.; Thierauf, A.; Auwärter, V. Fatal doxepin intoxication-suicide or slow gradual intoxication? Forensic Sci. Int. 2013, 227, 82-84. [CrossRef] [PubMed]

35. Madadi, P.; Hildebrandt, D.; Gong, I.Y.; Schwarz, U.I.; Ciszkowski, C.; Ross, C.J.; Sistonen, J.; Carleton, B.C.; Hayden, M.R.; Lauwers, A.E.; et al. Fatal hydrocodone overdose in a child: Pharmacogenetics and drug interactions. Pediatrics 2010, 126, 986-989. [CrossRef]

36. Launiainen, T.; Rasanen, I.; Vuori, E.; Ojanperä, I. Fatal venlafaxine poisonings are associated with a high prevalence of drug interactions. Int. J. Leg. Med. 2011, 125, 349-358. [CrossRef] [PubMed]

37. Riccardi, L.N.; Lanzellotto, R.; Falconi, M.; Ceccardi, S.; Bini, C.; Pelotti, S. Development of a tetraplex PCR assay for CYP2D6 genotyping in degraded DNA samples. J. Forensic Sci. 2014, 59, 690-695. [CrossRef]

38. Jakobsson, G.; Larsson, R.; Pellè, L.; Kronstrand, R.; Gréen, H. Oxycodone findings and CYP2D6 function in postmortem cases. Forensic Sci. Int. Genet. 2021, 53, 102510. [CrossRef]

39. Vevelstad, M.; Øiestad, E.L.; Bremer, S.; Bogen, I.L.; Zackrisson, A.L.; Arnestad, M. Is toxicity of PMMA (paramethoxymethamphetamine) associated with cytochrome P450 pharmacogenetics? Forensic Sci. Int. 2016, 261, 137-147. [CrossRef]

40. Wu, A.H.; Kearney, T. Lack of impairment due to confirmed codeine use prior to a motor vehicle accident: Role of pharmacogenomics. J. Forensic Leg. Med. 2013, 20, 1024-1027. [CrossRef]

41. Bastami, S.; Haage, P.; Kronstrand, R.; Kugelberg, F.C.; Zackrisson, A.L.; Uppugunduri, S. Pharmacogenetic aspects of tramadol pharmacokinetics and pharmacodynamics after a single oral dose. Forensic Sci. Int. 2014, 238, 125-132. [CrossRef]

42. Levo, A.; Koski, A.; Ojanperä, I.; Vuori, E.; Sajantila, A. Post-mortem SNP analysis of CYP2D6 gene reveals correlation between genotype and opioid drug (tramadol) metabolite ratios in blood. Forensic Sci. Int. 2003, 135, 9-15. [CrossRef]

43. Koren, G.; Cairns, J.; Chitayat, D.; Gaedigk, A.; Leeder, S.J. Pharmacogenetics of morphine poisoning in a breastfed neonate of a codeine-prescribed mother. Lancet 2006, 368, 704. [CrossRef]

44. Piatkov, I.; Jones, T.; Van Vuuren, R.J. Suicide cases and venlafaxine. Acta Neuropsychiatr 2011, 23, 156-160. [CrossRef] [PubMed] 
45. Rahikainen, A.L.; Palo, J.U.; Haukka, J.; Sajantila, A. Post-mortem analysis of suicide victims shows ABCB1 haplotype 1236T2677T-3435T as a candidate predisposing factor behind adverse drug reactions in females. Pharm. Genom. 2018, $28,99-106$. [CrossRef]

46. Drevin, G.; Picard, N.; Jousset, N.; Briet, M.; Abbara, C. Pitfalls and challenges associated with phenoconversion in forensic toxcicology. Forensic Sci. Int. Genet. 2021, 51, 102433. [CrossRef] [PubMed]

47. Neuvonen, A.M.; Palo, J.U.; Sajantila, A. Post-mortem ABCB1 genotyping reveals an elevated toxicity for female digoxin users. Int. J. Legal Med. 2011, 125, 265-269. [CrossRef]

48. Fonseca, S.; Amorim, A.; Costa, H.A.; Franco, J.; Porto, M.J.; Santos, J.C.; Dias, M. Sequencing CYP2D6 for the detection of poor-metabolizers in post-mortem blood samples with tramadol. Forensic Sci. Int. 2016, 265, 153-159. [CrossRef]

49. Buchard, A.; Linnet, K.; Johansen, S.S.; Munkholm, J.; Fregerslev, M.; Morling, N. Postmortem blood concentrations of R- and S-enantiomers of methadone and EDDP in drug users: Influence of co-medication and p-glycoprotein genotype. J. Forensic Sci. 2010, 55, 457-463. [CrossRef]

50. Karlsson, L.; Zackrisson, A.L.; Josefsson, M.; Carlsson, B.; Green, H.; Kugelberg, F.C. Influence of CYP2D6 and CYP2C19 genotypes on venlafaxine metabolic ratios and stereoselective metabolism in forensic autopsy cases. Pharm. J. 2015, 15, 165-171. [CrossRef]

51. Andresen, H.; Augustin, C.; Streichert, T. Toxicogenetics-Cytochrome P450 microarray analysis in forensic cases focusing on morphine/codeine and diazepam. Int. J. Leg. Med. 2013, 127, 395-404. [CrossRef] [PubMed]

52. Jannetto, P.J.; Wong, S.H.; Gock, S.B.; Laleli-Sahin, E.; Schur, B.C.; Jentzen, J.M. Pharmacogenomics as molecular autopsy for postmortem forensic toxicology: Genotyping cytochrome P450 2D6 for oxycodone cases. J. Anal. Toxicol. 2002, 26, 438-447. [CrossRef]

53. Mamdani, F.; Berlim, M.T.; Beaulieu, M.M.; Labbe, A.; Merette, C.; Turecki, G. Gene expression biomarkers of response to citalopram treatment in major depressive disorder. Transl. Psychiatry 2011, 1, 13. [CrossRef] [PubMed]

54. Skadrić, I.; Stojković, O. Defining screening panel of functional variants of CYP1A1, CYP2C9, CYP2C19, CYP2D6, and CYP3A4 genes in Serbian population. Int. J. Leg. Med. 2020, 134, 433-439. [CrossRef]

55. Turillazzi, E.; La Rocca, G.; Anzalone, R.; Corrao, S.; Neri, M.; Pomara, C.; Riezzo, I.; Karch, S.B.; Fineschi, V. Heterozygous nonsense SCN5A mutation W822X explains a simultaneous sudden infant death syndrome. Virchows Arch. 2008, 453, 209-216. [CrossRef] [PubMed]

56. Salerno, M.; Villano, I.; Nicolosi, D.; Longhitano, L.; Loreto, C.; Lovino, A.; Sessa, F.; Polito, A.N.; Monda, V.; Chieffi, S.; et al. Modafinil and orexin system: Interactions and medico-legal considerations. Front. Biosci. 2019, 24, 564-575. [CrossRef]

57. Pitsiladis, Y.P.; Tanaka, M.; Eynon, N.; Bouchard, C.; North, K.N.; Williams, A.G.; Collins, M.; Moran, C.N.; Britton, S.L.; Fuku, N.; et al. Athlome Project Consortium. Athlome Project Consortium: A concerted effort to discover genomic and other "omic" markers of athletic performance. Physiol. Genomics 2016, 48, 183-190. [CrossRef] [PubMed]

58. Ingelman-Sundberg, M.; Sim, S.C.; Gomez, A.; Rodriguez-Antona, C. Influence of cytochrome P450 polymorphisms on drug therapies: Pharmacogenetic, pharmacoepigenetic and clinical aspects. Pharmacol. Ther. 2007, 116, 496-526. [CrossRef] [PubMed]

59. Boyle, J.; Stock, C.J. CYP2D6 Expression in Veterans Experiencing Opioid Overdose: A Postmortem Review. Pharmgenomics Pers. Med. 2020, 13, 289-293. [CrossRef] [PubMed]

60. Snider, N.T.; Sikora, M.J.; Sridar, C.; Feuerstein, T.J.; Rae, J.M.; Hollenberg, P.F. The endocannabinoid anandamide is a substrate for the human polymorphic cytochrome P450 2D6. J. Pharmacol. Exp. Ther. 2008, 327, 538-545. [CrossRef]

61. Sridar, C.; Snider, N.T.; Hollenberg, P.F. Anandamide oxidation by wild-type and polymorphically expressed CYP2B6 and CYP2D6. Drug Metab. Dispos. 2011, 39, 782-788. [CrossRef] [PubMed]

62. Sessa, F.; Salerno, M.; Di Mizio, G.; Bertozzi, G.; Messina, G.; Tomaiuolo, B.; Pisanelli, D.; Maglietta, F.; Ricci, P.; Pomara, C. Anabolic Androgenic Steroids: Searching New Molecular Biomarkers. Front. Pharmacol. 2018, 9, 1321. [CrossRef] [PubMed]

63. Albano, G.D.; Sessa, F.; Messina, A.; Monda, V.; Bertozzi, G.; Maglietta, F.; Giugliano, P.; Vacchiano, G.; Gabriella, M.; Salerno, M. AAS and organs damage: A focus on Nandrolone effects. Acta Med. Mediterr. 2017, 6, 939-946.

64. Lucas, D.; Goulitquer, S.; Marienhagen, J.; Fer, M.; Dreano, Y.; Schwaneberg, U.; Amet, Y.; Corcos, L. Stereoselective epoxidation of the last double bond of polyunsaturated fatty acids by human cytochromes P450. J. Lipid Res. 2010, 51, 1125-1133. [CrossRef] [PubMed]

65. Honda, A.; Miyazaki, T.; Ikegami, T.; Iwamoto, J.; Maeda, T.; Hirayama, T.; Saito, Y.; Teramoto, T.; Matsuzaki, Y. Cholesterol 25-hydroxylation activity of CYP3A. J. Lipid Res. 2011, 52, 1509-1516. [CrossRef]

66. Chen, H.; Howald, W.N.; Juchau, M.R. Biosynthesis of all-trans-retinoic acid from all-trans-retinol: Catalysis of all-trans-retinol oxidation by human P-450 cytochromes. Drug Metab. Dispos. 2000, 28, 315-322.

67. Wendt, F.R.; Sajantila, A.; Moura-Neto, R.S.; Woerner, A.E.; Budowle, B. Full-gene haplotypes refine CYP2D6 metabolizer phenotype inferences. Int. J. Leg. Med. 2018, 132, 1007-1024. [CrossRef]

68. Nebert, D.W. Polymorphisms in drug-metabolizing enzymes: What is their clinical relevance and why do they exist? Am. J. Hum. Genet. 1997, 60, 265-271. [PubMed]

69. Ingelman-Sundberg, M. Genetic polymorphisms of cytochrome P450 2D6 (CYP2D6): Clinical consequences, evolutionary aspects and functional diversity. Pharm. J. 2005, 5, 6-13. [CrossRef]

70. Mercadante, S. Opioid metabolism and clinical aspects. Eur. J. Pharmacol. 2015, 769, 71-78. [CrossRef] 
71. Siegle, I.; Fritz, P.; Eckhardt, K.; Zanger, U.M.; Eichelbaum, M. Cellular localization and regional distribution of CYP2D6 mRNA and protein expression in human brain. Pharmacogenetics 2001, 11, 237-245. [CrossRef] [PubMed]

72. Esposito, M.; Cocimano, G.; Ministrieri, F.; Rosi, G.L.; Nunno, N.D.; Messina, G.; Sessa, F.; Salerno, M. Smart drugs and neuroenhancement: What do we know? Front. Biosci. 2021, 26, 347-359. [CrossRef]

73. Bertozzi, G.; Sessa, F.; Albano, G.D.; Sani, G.; Maglietta, F.; Roshan, M.H.K.; Volti, G.L.; Bernardini, R.; Avola, R.; Pomara, C.; et al The Role of Anabolic Androgenic Steroids in Disruption of the Physiological Function in Discrete Areas of the Central Nervous System. Mol. Neurobiol. 2018, 55, 5548-5556. [CrossRef] [PubMed]

74. Kornhuber, J.; Bleich, S. Actions of psychotropic drugs beyond their primary targets at the synaptic cleft. Eur. Arch. Psychiatry Clin. Neurosci. 2006, 256, 265-267. [CrossRef]

75. Maeda, K.; Sugiyama, Y. Impact of genetic polymorphisms of transporters on the pharmacokinetic, pharmacodynamic and toxicological properties of anionic drugs. Drug Metab. Pharm. 2008, 23, 223-235. [CrossRef]

76. Esposito, M.; Licciardello, G.; Privitera, F.; Iannuzzi, S.; Liberto, A.; Sessa, F.; Salerno, M. Forensic Post-Mortem Investigation in AAS Abusers: Investigative Diagnostic Protocol. A Systematic Review. Diagnostics 2021, 11, 1307. [CrossRef] [PubMed]

77. Tzang, R.F.; Hong, C.J.; Liou, Y.J.; Yu, Y.W.; Chen, T.J.; Tsai, S.J. Association study of p11 gene with major depressive disorder, suicidal behaviors and treatment response. Neurosci. Lett. 2008, 447, 92-95. [CrossRef] [PubMed]

78. Budowle, B.; Van Daal, A. Extracting evidence from forensic DNA analyses: Future molecular biology directions. Biotechniques 2009, 46, 342-350. [CrossRef]

79. Turillazzi, E.; Baroldi, G.; Silver, M.D.; Parolini, M.; Pomara, C.; Fineschi, V. A systematic study of a myocardial lesion: Colliquative myocytolysis. Int. J. Cardiol. 2005, 104, 152-157. [CrossRef] [PubMed]

80. Agrawal, Y.P.; Rennert, H. Pharmacogenomics and the future of toxicology testing. Clin. Lab. Med. 2012, 32, 509-523. [CrossRef]

81. Wyman, J.F. Principles and procedures in forensic toxicology. Clin. Lab. Med. 2012, 32, 493-507. [CrossRef] [PubMed]

82. Sajantila, A.; Palo, J.U.; Ojanperä, I.; Davis, C.; Budowle, B. Pharmacogenetics in medico-legal context. Forensic Sci. Int. 2010, 203, 44-52. [CrossRef] [PubMed]

83. Sessa, F.; Esposito, M.; Messina, G.; Di Mizio, G.; Di Nunno, N.; Salerno, M. Sudden Death in Adults: A Practical Flow Chart for Pathologist Guidance. Healthcare 2021, 9, 870. [CrossRef] [PubMed]

84. Musshoff, F.; Stamer, U.M.; Madea, B. Pharmacogenetics and forensic toxicology. Forensic Sci. Int. 2010, 203, 53-62. [CrossRef]

85. Salerno, M.; Cascio, O.; Bertozzi, G.; Sessa, F.; Messina, A.; Monda, V.; Cipolloni, L.; Biondi, A.; Daniele, A.; Pomara, C. Anabolic androgenic steroids and carcinogenicity focusing on Leydig cell: A literature review. Oncotarget 2018, 9, 19415-19426. [CrossRef] [PubMed]

86. Bafunno, V.; Bury, L.; Tiscia, G.L.; Fierro, T.; Favuzzi, G.; Caliandro, R.; Sessa, F.; Grandone, E.; Margaglione, M.; Gresele, P. A novel congenital dysprothrombinemia leading to defective prothrombin maturation. Thromb. Res. 2014, 134, $1135-1141$. [CrossRef]

87. Caenazzo, L.; Tozzo, P. The Future of Biobanking: What Is Next? BioTech 2020, 9, 23. [CrossRef]

88. Rebsamen, M.C.; Desmeules, J.; Daali, Y.; Chiappe, A.; Diemand, A.; Rey, C.; Chabert, J.; Dayer, P.; Hochstrasser, D.; Rossier, M.F. The AmpliChip CYP450 test: Cytochrome P450 2D6 genotype assessment and phenotype prediction. Pharm. J. 2009, 9, 34-41. [CrossRef]

89. Shimizu, M.; Sawaya, R.; Kishimoto, I.; Yamazaki, H. Genotyping of wild-type cytochrome P450 2A6 and whole-gene deletion using human blood samples and a multiplex real-time polymerase chain reaction method with dual-labeled probes. Clin. Chim. Acta 2015, 441, 71-74. [CrossRef] [PubMed]

90. Stamer, U.M.; Bayerer, B.; Wolf, S.; Hoeft, A. Rapid and reliable method for cytochrome P450 2D6 genotyping. Clin. Chem. 2002, 48, 1412-1417. [CrossRef]

91. Muller, B.; Zopf, K.; Bachofer, J.; Steimer, W. Optimized strategy for rapid cytochrome P450 2D6 genotyping by real-time long PCR. Clin. Chem. 2003, 49, 624-1631. [CrossRef]

92. Alaeddini, R. Forensic implications of PCR inhibition-A review. Scie Int. Genet. 2012, 6, 297-305. [CrossRef] [PubMed]

93. Zubakov, D.; Boersma, A.W.; Choi, Y.; van Kuijk, P.F.; Wiemer, E.A.; Kayser, M. MicroRNA markers for forensic body fluid identification obtained from microarray screening and quantitative RT-PCR confirmation. Int. J. Leg. Med. 2010, 124, 217-226. [CrossRef] [PubMed]

94. Qiao, W.; Yang, Y.; Sebra, R.; Mendiratta, G.; Gaedigk, A.; Desnick, R.J.; Scott, S.A. Long-read single molecule real-time full gene sequencing of cytochrome P450-2D6. Hum. Mutat. 2016, 37, 315-323. [CrossRef] [PubMed]

95. Lai, Y.L.; Chung, Y.K.; Tan, H.C. Cost-effective real-time reverse transcriptase PCR (RT-PCR) to screen for Dengue virus followed by rapid single-tube multiplex RT-PCR for serotyping of the virus. J. Clin. Microbiol. 2007, 45, 935-941. [CrossRef] [PubMed]

96. Rouet, F.; Ekouevi, D.K.; Chaix, M.L.; Burgard, M.; Inwoley, A.; Tony, T.D.A.; Danel, C.; Anglaret, X.; Leroy, V.; Msellati, P.; et al. Transfer and evaluation of an automated, low-cost real-time reverse transcription-PCR test for diagnosis and monitoring of human immunodeficiency virus type 1 infection in a West African resource-limited setting. J. Clin. Microbiol. 2005, 43, $2709-2717$. [CrossRef] [PubMed]

97. Pomara, C.; Salerno, M.; Sessa, F.; Esposito, M.; Barchitta, M.; Ledda, C.; Grassi, P.; Liberto, A.; Mattaliano, A.R.; Rapisarda, V.; et al. Safe Management Strategies in Clinical Forensic Autopsies of Confirmed COVID-19 Cases. Diagnostics 2021, $11,457$. [CrossRef] [PubMed] 
98. Musso, N.; Falzone, L.; Stracquadanio, S.; Bongiorno, D.; Salerno, M.; Esposito, M.; Sessa, F.; Libra, M.; Stefani, S.; Pomara, C. Post-Mortem Detection of SARS-CoV-2 RNA in Long-Buried Lung Samples. Diagnostics 2021, 11, 1158. [CrossRef] [PubMed]

99. Pomara, C.; Sessa, F.; Galante, D.; Pace, L.; Fasanella, A.; Di Nunno, N.; Esposito, M.; Salerno, M. Do We Really Need Hazard Prevention at the Expense of Safeguarding Death Dignity in COVID-19? Diagnostics 2021, 11, 1913. [CrossRef]

100. Pomara, C.; Sessa, F.; Ciaccio, M.; Dieli, F.; Esposito, M.; Giammanco, G.M.; Garozzo, S.F.; Giarratano, A.; Prati, D.; Rappa, F.; et al. COVID-19 Vaccine and Death: Causality Algorithm According to the WHO Eligibility Diagnosis. Diagnostics 2021, 11, 955. [CrossRef] [PubMed]

101. Warner, M.; Trinidad, J.P.; Bastian, B.A.; Miniño, A.M.; Hedegaard, H. Drugs most frequently involved in drug overdose deaths: United States. Natl. Vital Stat. Rep. 2016, 65, 1-15. [PubMed]

102. Hedegaard, H.; Bastian, B.A.; Trinidad, J.P.; Spencer, M.; Warner, M. Drugs most frequently involved in drug overdose deaths: United States. Natl. Vital Stat. Rep. 2018, 67, 1-14. [PubMed]

103. Hedegaard, H.; Miniño, A.M.; Warner, M. Urban-rural differences in drug overdose death rates, by sex, age, and type of drugs onvolved. Natl. Vital Stat. Rep. 2019, 345, 1-8.

104. Jones, C.M.; Mack, K.A.; Paulozzi, L.J. Pharmaceutical overdose deaths, united states, 2010. JAMA 2013, 309, 657-659. [CrossRef] [PubMed]

105. Caenazzo, L.; Tozzo, P.; Dierickx, K. Incidental findings in forensics: Are we sure that it is a question easy to deal with? Int. J. Leg. Med. 2021, 135, 591-592. [CrossRef]

106. Calcaterra, S.; Glanz, J.; Binswanger, I.A. National trends in pharmaceutical opioid related overdose deaths compared to other substance related overdose deaths: 1999-2009. Drug Alcohol. Depend. 2013, 131, 263-270. [CrossRef]

107. Cryer, B. NSAID-associated deaths: The rise and fall of NSAID-associated GI mortality. Am. J. Gastroenterol. 2005, 100, 1694-1695. [CrossRef] [PubMed]

108. Goldkind, L.; Laine, L. A systematic review of NSAIDs withdrawn from the market due to hepatotoxicity: Lessons learned from the bromfenac experience. Pharmacoepidemiol. Drug Saf. 2006, 15, 213-220. [CrossRef]

109. Bafunno, V.; Santacroce, R.; Chetta, M.; D’Andrea, G.; Pisanelli, D.; Sessa, F.; Trotta, T.; Tagariello, G.; Peyvandi, F.; Margaglione, M. Polymorphisms in genes involved in autoimmune disease and the risk of FVIII inhibitor development in Italian patients with haemophilia A. Haemophilia 2010, 16, 469-473. [CrossRef] [PubMed]

110. Santacroce, R.; Santoro, R.; Sessa, F.; Iannaccaro, P.; Sarno, M.; Longo, V.; Gallone, A.; Vecchione, G.; Muleo, G.; Margaglione, M. Screening of mutations of hemophilia A in 40 Italian patients: A novel G-to-A mutation in intron 10 of the F8 gene as a putative cause of mild hemophilia A in southern Italy. Blood Coagul. Fibrinolysis. 2008, 19, 197-202. [CrossRef]

111. Patanè, F.G.; Esposito, M.; Musumeci, A.G.; Palermo, M.; Torrisi, M.; Salerno, M.; Montana, A. Multidisciplinary Approach to Suspected Sudden Death Caused by Arteriovenous Malformation Rupture: A Case Report. Medicina 2021, 57, 644. [CrossRef]

112. Bonn, D. Adverse drug reactions remain a major cause of death. Lancet 1998, 351, 1183. [CrossRef]

113. Sessa, F.; Polito, R.; Monda, V.; Scarinci, A.; Salerno, M.; Carotenuto, M.; Cibelli, G.; Valenzano, A.; Campanozzi, A.; Mollica, M.P.; et al. Effects of a Plastic-Free Lifestyle on Urinary Bisphenol A Levels in School-Aged Children of Southern Italy: A Pilot Study. Front. Public Health 2021, 9, 626070. [CrossRef] [PubMed]

114. Bafunno, V.; Santacroce, R.; Chetta, M.; Peyvandi, F.; Sessa, F.; Chinni, E.; Longo, V.; Margaglione, M. Polymorphic miRNAmediated gene contribution to inhibitor development in haemophilia A. Haemophilia 2012, 18, 1003-1007. [CrossRef] [PubMed]

115. Guerrini, K.; Argo, A.; Borroni, C.; Catalano, D.; Dell'acqua, L.; Farè, F.; Procaccianti, P.; Roda, G.; Gambaro, V. Development and validation of a reliable method for studying the distribution pattern for opiates metabolites in brain. J. Pharm. Biomed. Anal. 2013, 73, 125-130. [CrossRef] [PubMed] 